Article

\title{
Synthesis, Structural Studies and Antitumoral Evaluation of C-6 Alkyl and Alkenyl Side Chain Pyrimidine Derivatives
}

Svjetlana Krištafor ${ }^{1}$, Tatjana Gazivoda Kraljević ${ }^{1}$, Damjan Makuc ${ }^{2}$, Janez Plavec ${ }^{2}$, Lidija Šuman $^{3}$, Marijeta Kralj ${ }^{3}$ and Silvana Raić-Malić ${ }^{1, *}$

1 Department of Organic Chemistry, Faculty of Chemical Engineering and Technology, University of Zagreb, Marulićev trg 20, P.O. Box 177, HR-10000 Zagreb, Croatia;

E-Mails: prekupec@fkit.hr (S.K.); tgazivod@fkit.hr (T.G.K.)

2 Slovenian NMR Centre, National Institute of Chemistry, Hajdrihova 19, P.O. Box 660, SI-1001

Ljubljana, Slovenia; E-Mails: damjan.makuc@ki.si (D.M.); janez.plavec@ki.si (J.P.)

3 Division of Molecular Medicine, Ruđer Bošković Institute, Bijenička 54, P.O. Box 1016, HR10001, Zagreb, Croatia; E-Mails: lidija.suman@irb.hr (L.S.); marijeta.kralj@irb.hr (M.K.)

* Author to whom correspondence should be addressed; E-Mail: silvana.raic@fkit.hr; Tel.: +38 514597 213; Fax: +38 514597224.

Received: 30 September 2009; in revised form: 19 November 2009 / Accepted: 25 November 2009 / Published: 27 November 2009

\begin{abstract}
The synthetic route for introduction of fluorophenylalkyl (compounds 5, 7, 14 and 15) and fluorophenylalkenyl (compounds $\mathbf{4 E}$ and 13) side chains at C-6 of the pyrimidine nucleus involved the lithiation of the pyrimidine derivatives $\mathbf{1}, \mathbf{2}$ and $\mathbf{1 1}$ and subsequent nucleophilic addition or substitution reactions of the organolithium intermediate thus obtained with 2-fluorophenylacetone, 4-fluoroacetophenone or ethyl 4-fluorobenzoate as electrophiles. The structures of novel compounds were confirmed by ${ }^{1} \mathrm{H}-,{ }^{19} \mathrm{~F}-$ and ${ }^{13} \mathrm{C}-\mathrm{NMR}$ and MS. Compounds $\mathbf{8}$ and $\mathbf{1 0}$ containing unsaturated fluorophenylalkyl side chains showed better inhibitory effect than their saturated fluorophenylalkylated pyrimidine counterparts $\mathbf{7}$ and $\mathbf{9}$. A conformational study based on NOE enhancements showed the importance of the double bond and substitution in the side chain for the conformational preferences in relation to inhibitory activity. Among all tested compounds, C-5 furyl (12) and phenyl (13 and 15) substituted pyrimidine derivatives showed significant cytostatic activities against all tested tumor cell lines.
\end{abstract}


Keywords: C-6 alkyl and alkenyl pyrimidine derivatives; NMR conformational analysis; cytostatic activity evaluations

\section{Introduction}

The application of fluorine-containing compounds in the pharmaceutical and agrochemical fields has a very short history [1,2]. The small size of the fluorine substituent, combined with its high electronegativity and its impact upon bond strengths give rise to the observed distinctive effect of fluorine substituents on the biological activity of compounds [3]. In the area of medicinal chemistry, incorporation of fluorine has played a significant role in the development of new anti-cancer and anti-viral agents, anti-inflammatory and anti-hyperintensive agents, anti-fertility drugs and central nervous system drugs. Fluorine affects the biological activity of compounds in a number of important ways. It has been reported that covalently bonded fluorine is a very weak intermolecular hydrogenbond acceptor [4]. The presence of fluorine at a particular position in a molecule can enhance its metabolic stability or modulate its physicochemical properties, such as its lipophilicity, acidity or basicity. Fluorination can increase molecules' binding affinity to a target protein, and by a combination of factors interfere with specific enzyme action [2,5]. As a result, the introduction of fluorine atoms, trifluoromethyl, difluoromethyl or other fluorinated and fluoroalkyl groups into heterocyclic compounds may have significant influence on their biological and physical properties. Therefore, fluorinated compounds in general and fluorinated heterocycles in particular are the focus of much research [2]. Pyrimidines are biologically important molecules and valuable heterocyclic nuclei for the design of pharmaceutical agents [6,7]. A great number of C-5 and C-6 substituted pyrimidine nucleosides have been prepared in view of their various biological activities [8]. For this reason, the development of synthetic methods for fluorine-containing heterocyclic compounds has been an important field in both organofluorine chemistry and organic synthesis.

Recently, we have reported that fluorinated propyl or propenyl C-6 acyclic pyrimidine derivatives containing the 2-hydroxy-3,3,3-trifluoro-1-propenyl side chain exhibited a pronounced effect against breast carcinoma (MCF-7), while the compound with a 2-fluoromethyl-2-acetoxypropyl chain exhibited moderate effect against cervical carcinoma (HeLa) [9]. We have also reported the synthesis and biological results of a new type of C-6 fluoroalkylated and fluorophenylalkylated pyrimidine derivatives as model compounds for development of tracer molecules in positron-emission tomography (PET) [10]. In this study we present the syntheses and antitumoral evaluations of C-6 fluorophenylalkyl $(6,9,14$ and 15), fluorophenylalkenyl $(4,8,10$ and 13) and 5-furyl-6-methyl (12) pyrimidine derivatives.

\section{Results and Discussion}

\section{Chemistry}

Key precursors 2,4-dimethoxy-6-methyl pyrimidine (1), 2,4-dimethoxy-5,6-dimethylpyrimidine (2) and 5-bromo-2,4-dimethoxy-6-methylpyrimidine (3) were prepared according to the procedure 
described in the literature $[11,12]$. The C-6 fluorophenylalkyl substituted pyrimidine derivatives 4, 5, 7 and 13-15 (Schemes 1 and 2) were synthesized by lithiation, which has been studied extensively as an important carbon-carbon bond forming reaction [13,14]. Fluorophenyl-propyl and -ethyl side chaind were introduced by lithiation and subsequent nucleophilic addition of pyrimidine derivatives $\mathbf{1}$ and $\mathbf{2}$ to 2-fluorophenylacetone and 4-fluoroacetophenone to give $\mathbf{5}$ and 7, respectively (Scheme 1).

Scheme 1. Synthesis of C-6 alkyl and alkenyl side chain pyrimidine derivatives (4-10).

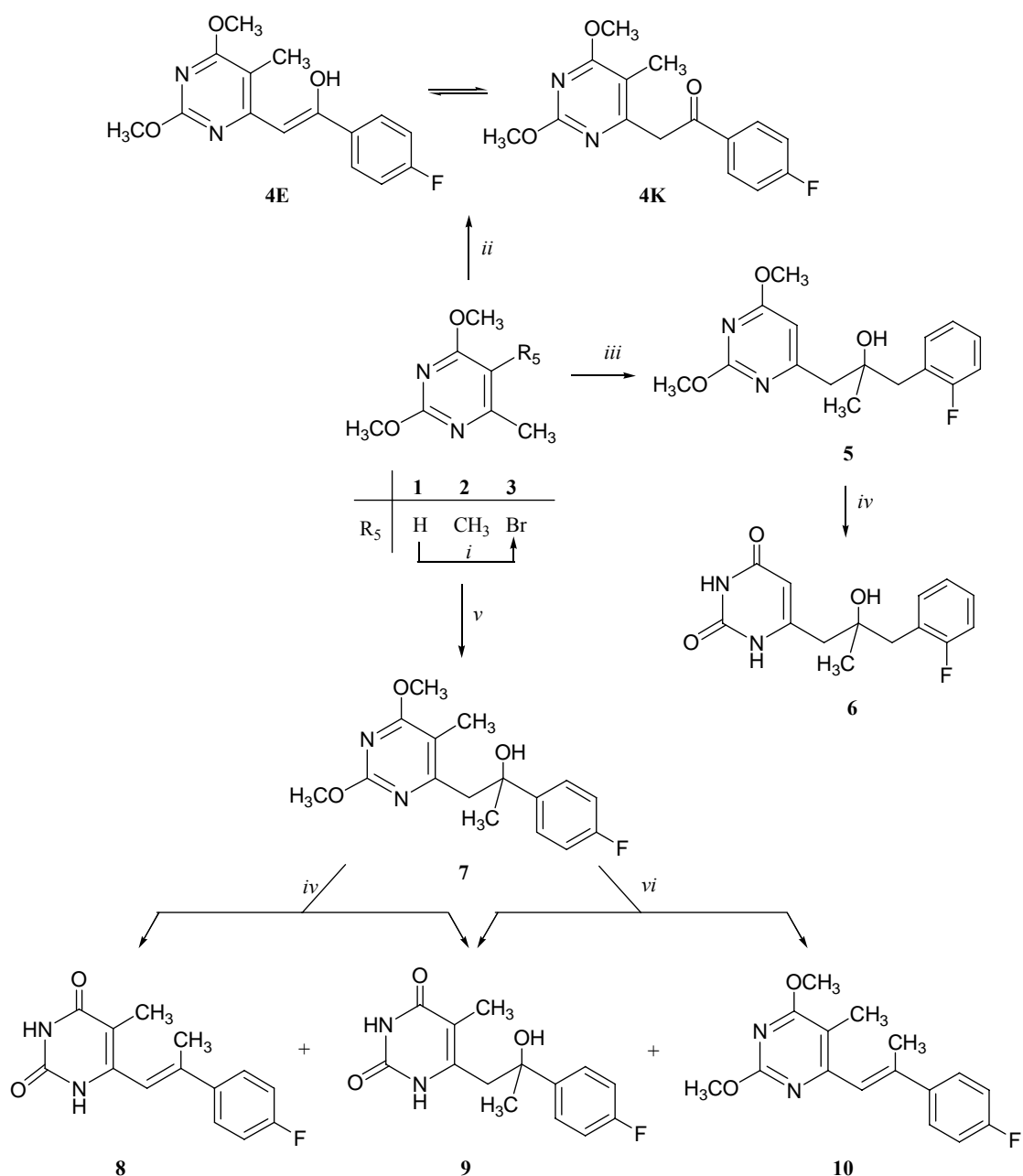

Reagents and conditions: (i) NBS, acetic acid; (ii) LDA, THF, ethyl 4-fluorobenzoate; (iii) LDA, THF, 2-fluorophenylacetone; (iv) $\mathrm{NaI},\left(\mathrm{CH}_{3}\right)_{3} \mathrm{SiCl}, \mathrm{CH}_{3} \mathrm{CN}$; (v) LDA, THF, 4-fluoroacetophenone; (vi) acetyl chloride, $\mathrm{H}_{2} \mathrm{O}$.

Reaction of lithiatied intermediate 2 with ethyl 4-fluorobenzoate afforded the C-6 substituted pyrimidine derivative containing unsaturated side chain, which exists as both the keto $(\mathbf{4 K})$ and enol (4E) tautomers (Scheme 1). The deprotection of 2,4-dimethoxypyrimidine derivative bearing C-6 fluorophenylalkyl side chain (5) with sodium iodide and trimethylchlorosilane gave pyrimidin-2,4dione derivative 6. Using the same synthetic procedure compound 7 yielded its unprotected pyrimidin2,4-dione derivatives with unsaturated (8) and saturated (9) fluorophenylalkyl side chain. Reaction of 7 with acetyl chloride and water gave deprotected pyrimidin-2,4-dione 9 and the 2,4dimethoxypyrimidine derivative $\mathbf{1 0}$ with unsaturated side chain as a product of dehydration reaction. The reason for production of unsaturated derivatives $\mathbf{8}$ and $\mathbf{1 0}$ is probably in enhanced stability of 
those compounds due to conjugated $\pi$-system of a pyrimidine and phenyl ring via side chain double bond, which is not present in compound 6 with the longer C-6 side chain.

The Stille reaction [15-17] was applied for the introduction of the phenyl and furyl rings at C-5 of pyrimidine moiety in $\mathbf{1 1}$ and 12, respectively, using tributylphenylstannane and tributylfurylstannane with dichlorobis(triphenylphosphine)palladium(II) as a catalyst. C-6 alkylation of 5-furylpyrimidine derivative 12 did not give desired fluorophenylalkylated 5-furylpyrimidine product. Nucleophilic substitution and addition reactions of lithiated 5-phenylpyrimidine derivative 11 with corresponding electrophile as reagent afforded pyrimidine derivatives containing $p$-fluorophenyl-2-hydroxyethenyl (13), $o$-fluorobenzyl-2-hydroxypropyl (14) and $p$-fluorophenyl-2-hydroxypropyl (15) side chain (Scheme 2).

Scheme 2. Synthesis of 5-phenylpyrimidine derivatives with C-6 fluorophenylalkyl side chain (13-15).

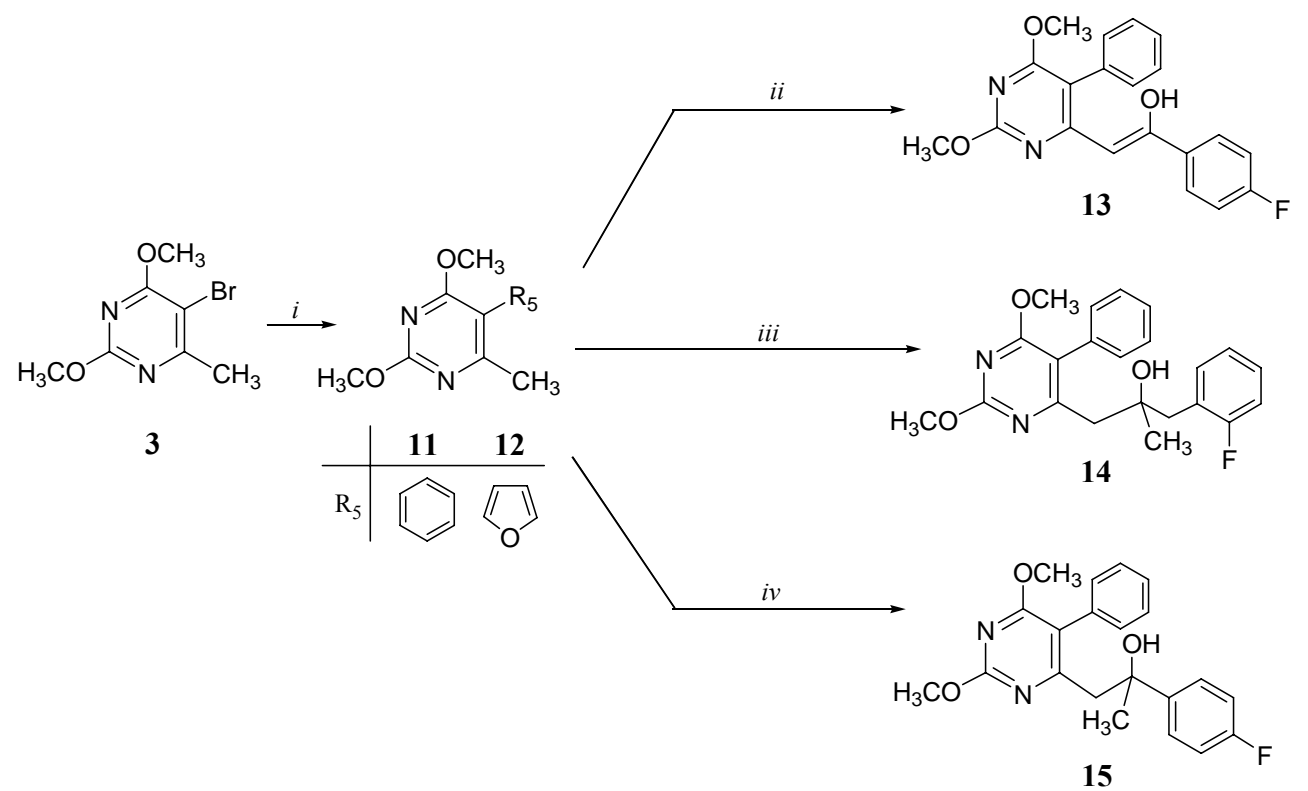

Reagents and conditions: (i) tributylphenylstannane/tributylfurylstannane, $\left(\mathrm{PPh}_{3}\right)_{2} \mathrm{PdCl}_{2}, \mathrm{THF}$; (ii)

LDA, THF, ethyl 4-fluorobenzoate; (iii) LDA, THF, 2-fluorophenylacetone; (iv) LDA, THF, 4-fluoroacetophenone.

\section{Antitumoral activities}

Compounds 4, 6, 8-10 and 12-15 were evaluated for their activities against human malignant tumor cell lines: Molt-4 (acute lymphoblastic leukemia), colon carcinoma (HCT 116 and SW 620), breast carcinoma (MCF-7) and lung carcinoma (H 460) (Table 1, Figure 1).

The results point to a strong impact of methyl, phenyl, or furyl C-5 substituents. For example, 5-unsubstituted pyrimidine derivatives bearing the same C-6 fluoroalkyl side chain as their structurally related 5-substituted pyrimidine derivatives did not exhibit any cytostatic effect, as shown in our previous paper [10]. In addition, pyrimidine derivative with fluorophenylalkylated side chain 4 exhibited moderate cytotoxic activity against all malignant tumor cells tested, particularly against human breast carcinoma (MCF-7, $\left.\mathrm{IC}_{50}=2 \mu \mathrm{M}\right)$. Furthermore, replacing of 5-methyl group (in 4 and 7) with 5-phenyl moiety (in $\mathbf{1 3}$ and 15) improves the antiproliferative activity by an order of magnitude. Moreover, comparing the activities of 2,4-dimethoxy-6-methyl-5-phenylpyrimidine (11) [10] and 
5-furyl-2,4-dimethoxy-6-methylpyrimidine (12) presented here $\left(\mathrm{IC}_{50}=2-10 \mu \mathrm{M}\right)$, it is obvious that replacing a phenyl with a furyl moiety strongly potentiates the antiproliferative activity. However, introduction of C-6 side chain in 5-phenylpyrimidine derivative $\mathbf{1 1}$ significantly increased the cytostatic effects of compounds 13-15. Conformationally restricted compounds $8\left(\mathrm{IC}_{50} \approx 69 \mu \mathrm{M}\right)$ and $10\left(\mathrm{IC}_{50} \approx 47 \mu \mathrm{M}\right)$ containing $\mathrm{C}-6$ unsaturated side chain showed higher antiproliferative effect than their analogues with saturated side chain $7\left(\mathrm{IC}_{50}>100 \mu \mathrm{M}\right)[10]$ and $9\left(\mathrm{IC}_{50}>100 \mu \mathrm{M}\right)$. Deprotection of 2,4-diketo functionalities of 5 and 7 caused a loss of activity for $\mathbf{6}$ and $\mathbf{9}$.

In conclusion, from C-6 fluorophenylalkyl substituted 2,4-dimethoxy-5-phenylpyrimidines (13-15), compounds $13\left(\mathrm{IC}_{50} \approx 2.5 \mu \mathrm{M}\right)$ and $15\left(\mathrm{IC}_{50} \approx 1.6 \mu \mathrm{M}\right)$ containing a $p$-fluorophenyl moiety in the side chain showed the most pronounced activity. The effect of the 5-furylpyrimidine $\mathbf{1 2}$ and 15, as the best representatives of the 5-phenylpyrimidine derivatives, were additionally tested on the cell cycle phases perturbation.

Table 1. Inhibitory effects of compounds 4, 6, 8-10 and 12-15 on the growth of human tumor cell lines.

\begin{tabular}{|c|c|c|c|c|c|}
\hline \multirow{2}{*}{ Compd } & \multicolumn{5}{|c|}{$\mathrm{IC}_{50}{ }^{a}(\boldsymbol{\mu} \mathrm{M})$} \\
\hline & Molt-4 & HCT 116 & SW 620 & MCF-7 & H 460 \\
\hline 4 & $43 \pm 41$ & $41 \pm 10$ & $32 \pm 19$ & $2 \pm 1$ & $19 \pm 5$ \\
\hline 6 & $>100$ & $>100$ & $>100$ & $>100$ & $>100$ \\
\hline 8 & $78 \pm 21$ & $79 \pm 21$ & $35 \pm 6$ & $51 \pm 18$ & $\geq 100$ \\
\hline 9 & $>100$ & $\geq 100$ & $>100$ & $>100$ & $>100$ \\
\hline 10 & $50 \pm 45$ & $37 \pm 0.03$ & $32 \pm 10$ & $42 \pm 1$ & $75 \pm 3$ \\
\hline 12 & $6 \pm 4$ & $3 \pm 0.3$ & $2 \pm 1.6$ & $10 \pm 6$ & $4 \pm 3$ \\
\hline 13 & N.T. ${ }^{b}$ & $2 \pm 0.2$ & $2 \pm 0.2$ & $3 \pm 1$ & $3 \pm 0.1$ \\
\hline 14 & N.T. ${ }^{b}$ & $14 \pm 0.1$ & $17 \pm 0.1$ & $14 \pm 3$ & $17 \pm 2$ \\
\hline 15 & $2 \pm 0.03$ & $1 \pm 0.5$ & $2 \pm 0.4$ & $2 \pm 1$ & $1 \pm 0.4$ \\
\hline
\end{tabular}

${ }^{a} \mathrm{IC}_{50} ; 50 \%$ inhibitory concentration, or compound concentration required to inhibit tumor cell proliferation by $50 \% ;{ }^{b}$ not tested.

Figure 1. Dose-response profiles for compounds 12 and 15. $\mathrm{PG}=$ percentage of growth.
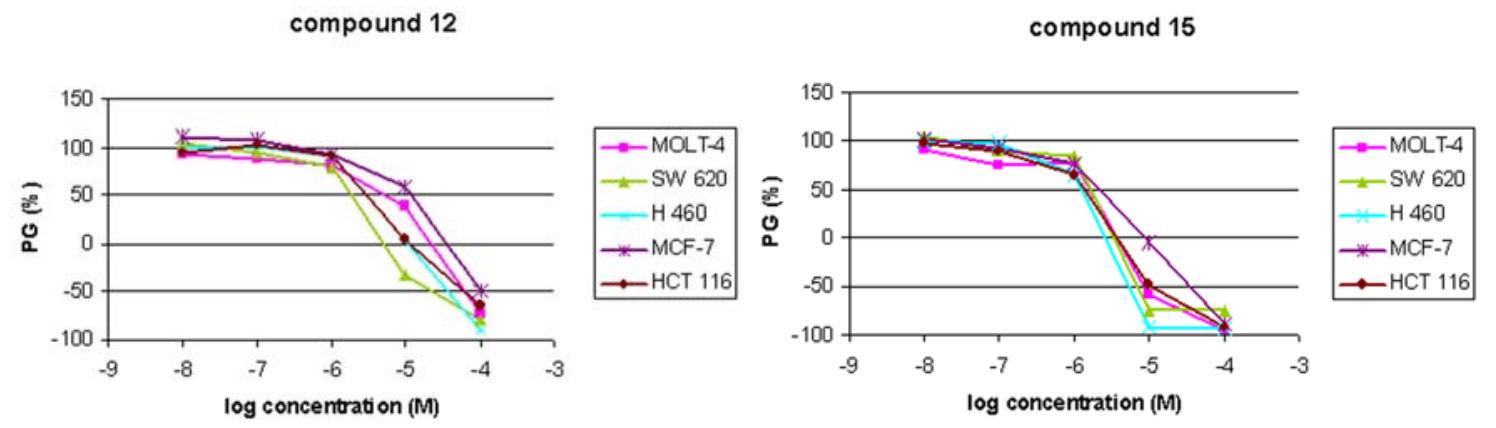

\section{Cell cycle perturbations}

Compounds 12 and 15 were tested at various concentrations close or slightly higher than their $\mathrm{IC}_{50}$ $(1,5$ and $10 \mu \mathrm{M})$ on HCT 116 cells (Figure 2). Both compounds showed similar influence on the cell cycle, whereby strong accumulation of cells in G1 cell cycle phase accompanied with drastic reduction 
of cells in S phase was detected. These effects were strongly dose-dependent. Moreover, compound 15 dose-dependently increased the percentage of cells in sub G1 after 48 hours of treatment, pointing to the induction of apoptosis. In addition, both compounds at $10 \mu \mathrm{M}$ concentration induced cell death of more than $30 \%$ of cells after 24 hours, while all cells were dead after 48 hours (not shown).

These results unambiguously point to the effects of here presented compounds on the cell cycle phenomena that occur probably during G1 phase and inhibit DNA synthesis, i.e. inhibit the progression of cell to next cell cycle phase. Being unable to progress through $\mathrm{S}$ phase to mitosis (M phase), the cells die, most probably by apoptosis.

Figure 2. Cell cycle analysis of HCT 116 cells treated with 1, 5 and $10 \mu \mathrm{M}$ compounds 12 and 15, $24 \mathrm{~h}$ (A and $\mathrm{C}$, respectively), or $48 \mathrm{~h}$ (B and $\mathrm{D}$, respectively). The histograms show percentages of live cells in $\mathrm{G} 0 / \mathrm{G} 1, \mathrm{~S}$ or $\mathrm{G} 2 / \mathrm{M}$ phase, along with the number of dead (subG1) cells, where subG1 population is expressed as a percentage of total number of measured cells/counts.

A

compound $12,24 \mathrm{~h}$

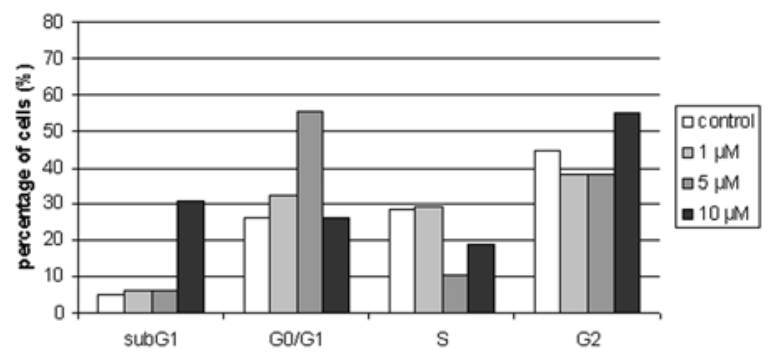

$\mathrm{C}$

compound $15,24 \mathrm{~h}$

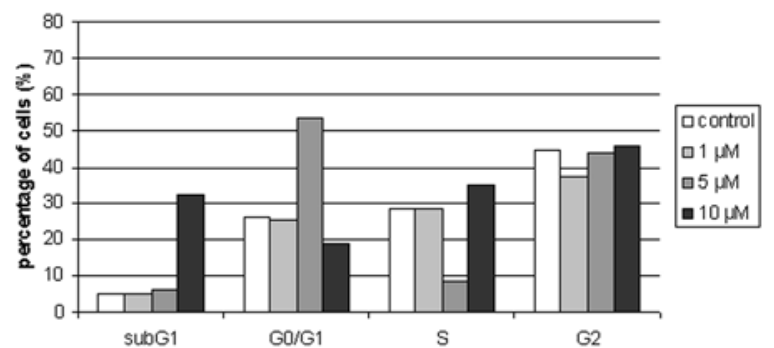

B

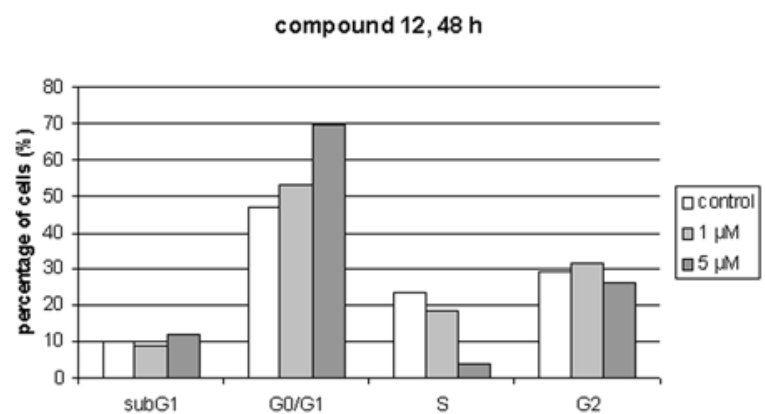

$\mathrm{D}$

compound $15,48 \mathrm{~h}$

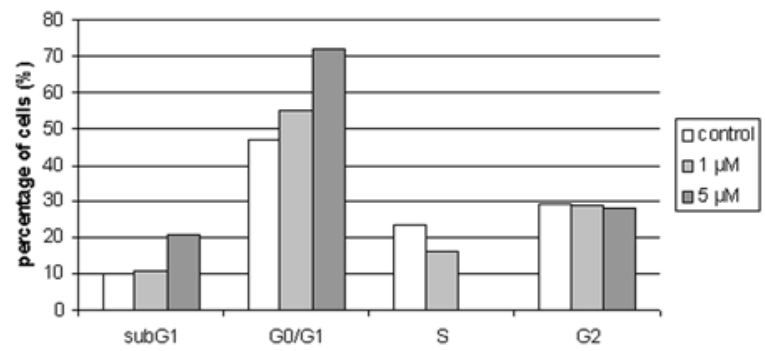

Structural and conformational studies by NMR

${ }^{1} \mathrm{H}-{ }^{19} \mathrm{~F}$ - and ${ }^{13} \mathrm{C}-\mathrm{NMR}$ data given in Table 2 and in the Experimental section are in full agreement with the structures of $4 \mathbf{E}, 4 \mathbf{K}, 6,8-10,13$ and 14. The observed chemical shifts of ${ }^{1} \mathrm{H}-$ and ${ }^{13} \mathrm{C}$ - resonances are characteristic of a C- 6 substituted pyrimidine moiety. 
Table 2. ${ }^{1} \mathrm{H}$ - and ${ }^{19} \mathrm{~F}-\mathrm{NMR}$ chemical shifts $(\delta / \mathrm{ppm})$, signal multiplicities and H-H coupling constants $(\mathrm{J} / \mathrm{Hz})$.

\begin{tabular}{|c|c|c|c|c|c|c|c|c|c|c|}
\hline Compd & N1-H & N3-H & H5 & H1' & $\begin{array}{l}\mathrm{C} 2^{\prime}- \\
\mathrm{OH}\end{array}$ & C2'-Me & C5-Me & $-\mathrm{OCH}_{3}$ & phenyl & ${ }^{19} \mathrm{~F}$ \\
\hline $4 E^{a}$ & - & - & - & $6.29(\mathrm{~s})$ & $\begin{array}{c}15.08 \\
(\mathrm{~s})\end{array}$ & - & $2.09(\mathrm{~s})$ & $3.95(\mathrm{~s})$ & $\begin{array}{l}7.97(\mathrm{~m}, \mathrm{H} \phi 2 / \mathrm{H} \phi 6) \\
7.29(\mathrm{~m}, \mathrm{H} \phi 3 / \mathrm{H} \phi 5)\end{array}$ & $-110.31(\mathrm{~m})$ \\
\hline $4 K^{a}$ & - & - & - & $4.48(\mathrm{~s})$ & - & - & $1.97(\mathrm{~s})$ & $\begin{array}{l}3.75(\mathrm{~s}), \\
3.91(\mathrm{~s})\end{array}$ & $\begin{array}{l}8.10(\mathrm{~m}, \mathrm{H} \phi 2 / \mathrm{H} \phi 6) \\
7.37(\mathrm{~m}, \mathrm{H} \phi 3 / \mathrm{H} \phi 5)\end{array}$ & $-105.21(\mathrm{~m})$ \\
\hline $6^{b}$ & $\begin{array}{c}10.92 \\
(\mathrm{~s})\end{array}$ & $\begin{array}{c}10.33 \\
(\mathrm{~s})\end{array}$ & $\begin{array}{l}5.37 \\
(\mathrm{~d})\end{array}$ & $2.46(d)$ & $\begin{array}{l}4.73 \\
(\mathrm{~s})\end{array}$ & $1.02(\mathrm{~s})$ & - & - & $\begin{array}{l}7.14(\mathrm{~m}, \mathrm{H} \phi 3) \\
7.27(\mathrm{~m}, \mathrm{H} \phi 4) \\
7.14(\mathrm{~m}, \mathrm{H} \phi 5) \\
7.33(\mathrm{~m}, \mathrm{H} \phi 6)\end{array}$ & $-115.83(\mathrm{~m})$ \\
\hline $\mathbf{8}^{c}$ & $\begin{array}{c}11.06 \\
(\mathrm{~s})\end{array}$ & $\begin{array}{c}10.59 \\
(\mathrm{~s})\end{array}$ & - & $6.39(\mathrm{~m})$ & - & $2.02(\mathrm{~d})$ & $1.70(\mathrm{~d})$ & - & $\begin{array}{l}7.64(\mathrm{~m}, \mathrm{H} \phi 2 / \mathrm{H} \phi 6) \\
7.24(\mathrm{~m}, \mathrm{H} \phi 3 / \mathrm{H} \phi 5)\end{array}$ & $-113.36(\mathrm{~m})$ \\
\hline $\mathbf{9}^{d}$ & $\begin{array}{c}10.93 \\
(\mathrm{~s}) \\
\end{array}$ & $\begin{array}{c}10.33 \\
(\mathrm{~s}) \\
\end{array}$ & - & $\begin{array}{l}2.73(d) \\
2.82(d)\end{array}$ & $\begin{array}{l}5.52 \\
\text { (b) }\end{array}$ & $1.52(\mathrm{~s})$ & $1.50(\mathrm{~s})$ & - & $\begin{array}{l}7.51(\mathrm{~m}, \mathrm{H} \phi 2 / \mathrm{H} \phi 6) \\
7.13(\mathrm{~m}, \mathrm{H} \phi 3 / \mathrm{H} \phi 5)\end{array}$ & - \\
\hline $10^{e}$ & - & - & - & $6.78(q)$ & - & $2.43(\mathrm{~d})$ & $2.06(\mathrm{~s})$ & $\begin{array}{l}3.89(\mathrm{~s}), \\
3.92(\mathrm{~s})\end{array}$ & $\begin{array}{l}7.66(\mathrm{~m}, \mathrm{H} \phi 2 / \mathrm{H} \phi 6) \\
7.24(\mathrm{~m}, \mathrm{H} \phi 3 / \mathrm{H} \phi 5)\end{array}$ & $-113.79(\mathrm{~m})$ \\
\hline 13 & - & - & - & $6.93(\mathrm{~s})$ & $\begin{array}{c}11.67 \\
(\mathrm{~s})\end{array}$ & - & - & $\begin{array}{l}3.79(\mathrm{~s}) \\
3.90(\mathrm{~s})\end{array}$ & $\begin{array}{c}7.40(\mathrm{~m}, \mathrm{H} \phi 2 / \mathrm{H} \phi 6) \\
7.33(\mathrm{~m}, \mathrm{H} \phi 3 / \mathrm{H} \phi 5) \\
7.22(\mathrm{~m}, 5 \mathrm{H} \phi)\end{array}$ & - \\
\hline $14^{f}$ & - & - & - & $2.61(\mathrm{~s})$ & $\begin{array}{l}5.19 \\
(\mathrm{~s})\end{array}$ & $0.95(\mathrm{~s})$ & - & $\begin{array}{l}3.80(\mathrm{~s}) \\
3.92(\mathrm{~s})\end{array}$ & $\begin{array}{l}7.17 \text { (m, Hф3) } \\
7.31(\mathrm{~m}, \mathrm{H} \phi 4) \\
7.19(\mathrm{~m}, \mathrm{H} \phi 5) \\
7.38(\mathrm{~m}, \mathrm{H} \phi 6) \\
7.02(\mathrm{~m}, 5 \mathrm{H} \phi)\end{array}$ & - \\
\hline
\end{tabular}

${ }^{\mathrm{a}}$ The $4 \mathrm{~K}: 4 \mathrm{E}$ ratio is ca. $55: 45$ as observed in ${ }^{1} \mathrm{H}$ and ${ }^{19} \mathrm{~F}$ NMR spectra; ${ }^{\mathrm{b}}{ }^{4} J_{\mathrm{H} 1}{ }^{\prime} \mathrm{H} 5=1.5$, multiplet for H3': 2.74 (d), 2.79 (d) with ${ }^{2} J_{\mathrm{H} \text { gem }}=13.4 \mathrm{~Hz} ;{ }^{\mathrm{c} 4} J_{\mathrm{H1} 1^{\prime} \mathrm{C} 2^{\prime} \mathrm{Me}}=1.2$ and ${ }^{5} J_{\mathrm{H} 1^{\prime}-\mathrm{C} 5 \mathrm{Me}}=0.6 \mathrm{~Hz} ;{ }^{\mathrm{d}{ }^{2}} J_{\mathrm{H} 1}$ ' gem

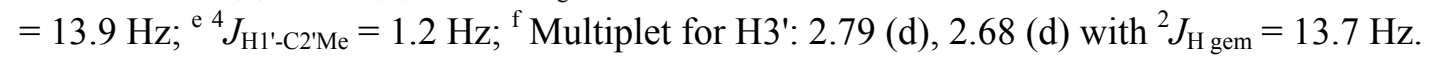

The conformational properties of $\mathbf{4 E}, \mathbf{8}$ and $\mathbf{1 0}$ and the configuration along $\mathrm{C} 1^{\prime}=\mathrm{C} 2{ }^{\prime}$ double bond were assessed with the use of 1D difference NOE experiments. The saturation of H1' $(\delta 6.29)$ in $\mathbf{4 E}$ resulted in strong $\mathrm{NOE}$ enhancements at $\mathrm{C} 5-\mathrm{Me}$ and $\phi 2 / \phi 6$-protons which confirmed the $Z$-configuration along $\mathrm{C}^{\prime}=\mathrm{C} 2{ }^{\prime}$ double bond (Figure $3 \mathrm{a}$ ). In addition, the saturation of $\mathrm{C} 5$-Me protons ( $\delta$ 2.09) resulted in NOE at $\mathrm{H}^{\prime}$ '. The observed NOE enhancements are in agreement with a conformation in which $\mathrm{C} 2$ '-OH group is predisposed for the formation of the $\mathrm{N} 1 \cdots \mathrm{HO}$ hydrogen bond as shown in Figure 3a. In fact, strongly deshielded ${ }^{1} \mathrm{H}-\mathrm{NMR}$ signal at $\delta 15.08 \mathrm{ppm}$ corresponding to hydroxyl group supports its involvement in hydrogen bond (Table 2). 
Figure 3. The key NOE enhancements and configuration along $\mathrm{C} 1^{\prime}=\mathrm{C} 2^{\prime}$ double bond for a) 4E, b) 8 and c) $\mathbf{1 0}$ in DMSO- $d_{6}$ solution.

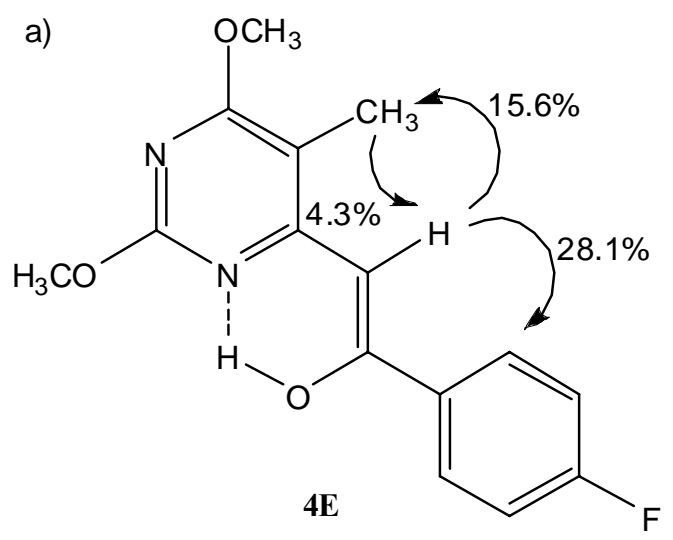

b)

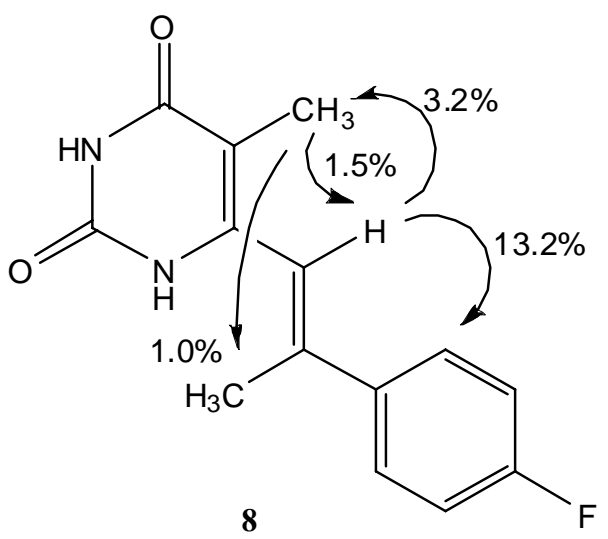

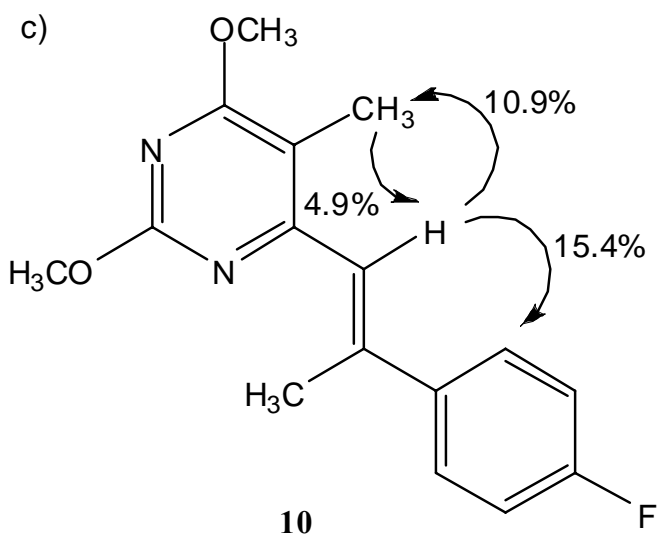

The saturation of H1' ( $\delta$ 6.39) in 8 showed strong NOE enhancements at $\phi 2 / \phi 6$-protons of fluorinated phenyl ring and none at $\mathrm{C}^{\prime}$-Me which is in agreement with $E$-configuration along $\mathrm{C}^{\prime}=\mathrm{C}^{\prime}$ double bond. On the other hand, the saturation of H1' resulted in a weak NOE enhancement at C5-Me group (Figure $3 \mathrm{~b})$. The saturation of C5-Me protons ( $\delta 1.70)$ showed weak NOE enhancements at both $\mathrm{H} 1$ ' and $\mathrm{C} 2$ '-Me group which suggested conformational freedom along C6-C1' single bond (Figure 3b).

The saturation of H1' $(\delta 6.78)$ in $\mathbf{1 0}$ resulted in strong NOE enhancements at C5-Me and $\phi 2 / \phi 6-$ protons of fluorinated phenyl ring (Figure 3c). The absence of NOEs with C2'-Me protons confirmed $E$-configuration along $\mathrm{C}^{\prime}=\mathrm{C} 2{ }^{\prime}$ double bond as shown in Figure 1c. Furthermore, the saturation of 
C5-Me protons $(\delta 2.06)$ showed NOE enhancement at H1'. These results are in agreement with the predominant conformation in which $\mathrm{H}^{\prime}$ ' is spatially closer to the C5-Me group.

\section{Experimental}

\section{General}

Melting points (uncorrected) were determined on a Kofler micro hot-stage (Reichert, Wien). Precoated Merck silica gel 60F-254 plates were used for thin layer chromatography (TLC) and the spots were detected under UV light $(254 \mathrm{~nm})$. Column chromatography (CLC) was performed using silica gel (0.063-0.2 mm) Fluka; glass column was slurry-packed under gravity. The electron impact mass spectra were recorded with an EXTREL FT MS 2001 instrument with ionizing energy $70 \mathrm{eV}$. Elemental analyses were performed in the Central Analytic Service, Ruđer Bošković Institute, Zagreb. ${ }^{1} \mathrm{H}-,{ }^{13} \mathrm{C}$ - and ${ }^{19} \mathrm{~F}-\mathrm{NMR}$ spectra were acquired on a Varian Unity Inova $300 \mathrm{MHz}$ NMR spectrometer. All data were recorded in DMSO- $d_{6}$ at $298 \mathrm{~K}$. Chemical shifts were referenced to the residual solvent signal of DMSO at $\delta 2.50 \mathrm{ppm}$ for ${ }^{1} \mathrm{H}$ and $\delta 39.50 \mathrm{ppm}$ for ${ }^{13} \mathrm{C}$, whereas fluorine chemical shifts were referenced relative to external $\mathrm{CCl}_{3} \mathrm{~F}(\delta 0.0 \mathrm{ppm})$. Individual resonances were assigned on the basis of their chemical shifts, signal intensities, multiplicity of resonances, $\mathrm{H}-\mathrm{H}$ coupling constants involved as well as with the use of a series of 2D NMR experiments (gHSQC and gHMBC).

\section{Procedures for the preparation of compounds}

2,4-Dimethoxy-6-methylpyrimidine (1), 2,4-dimethoxy-5,6-dimethylpyrimidine (2), 2,4-dimethoxy-6-methyl-5-bromopyrimidine (3), 6-[2-(2'-fluorobenzyl)-2-hydroxypropyl]-2,4-dimethoxypyrimidine (5), 6-[2-(4'-fluorophenyl)-2-hydroxypropyl]-2,4-dimethoxy-5-methyl-pyrimidine (7), 2,4dimethoxy-6-methyl-5-phenylpyrimidine (11), 5-furyl-2,4-dimethoxy-6-methylpyrimidine (12) and 6[2-(4'-fluorophenyl)-2-hydroxypropyl]-5-phenyl-2,4-dimethoxypyrimidine (15) were synthesized in accord with original procedures given in the literature [10-12,18].

\section{6-[2-(4'-Fluorophenyl)-2-hydroxyethenyl]-2,4-dimethoxy-5-methylpyrimidine (4)}

The solution of 2,4-dimethoxy-5,6-dimethylpyrimidine (2) (0.66 g, $3.94 \mathrm{mmol})$ in anhydrous THF $(10 \mathrm{~mL})$ was cooled at $-70{ }^{\circ} \mathrm{C}$ and lithium diisopropylamide (LDA, $2.91 \mathrm{~mL}, 2 \mathrm{M}$ in $\mathrm{THF} /$ heptane/ethylbenzene) was added dropwise to the reaction mixture. The temperature was then raised to $-55^{\circ} \mathrm{C}$ and the reaction mixture was stirred for $30 \mathrm{~min}$. Ethyl 4-fluorobenzoate $(0.69 \mathrm{~mL}$, $4.73 \mathrm{mmol}$ ) was added and the mixture was additionally stirred for $3 \mathrm{~h}$ and then neutralized with glacial acetic acid. The temperature was raised to room temperature and the reaction mixture was stirred for an additional $15 \mathrm{~min}$. The solvent was evaporated and the residual yellow oily product was extracted with $\mathrm{CH}_{2} \mathrm{Cl}_{2}$ and water. The organic layer was dried over $\mathrm{Na}_{2} \mathrm{SO}_{4}$ and purified by column chromatography using petroleum ether-ethyl acetate $=7: 1$ as eluent. After column chromatography, compound 4 was isolated as a mixture of $\mathbf{4 E}$ and $\mathbf{4 K}$. Yield $=0.28 \mathrm{~g}(24.7 \%) ; \mathrm{mp}=85-88^{\circ} \mathrm{C}$.

4E: ${ }^{13} \mathrm{C}-\mathrm{NMR}\left(\mathrm{DMSO}-d_{6}\right) \delta: 168.84(\mathrm{C} 4), 163.24\left(\mathrm{C} \phi 4, \mathrm{~d},{ }^{1} J_{\mathrm{CF}}=247.8\right), 163.13\left(\mathrm{C} 2\right.$ ', $\left.\mathrm{d},{ }^{5} J_{\mathrm{CF}}=0.6\right)$, 162.39 (C6), 160.28 (C2), 131.49 (C $\left.\phi 1, \mathrm{~d},{ }^{4} J_{\mathrm{CF}}=3.0\right), 128.84\left(\mathrm{C} \phi 2\right.$ and $\left.\mathrm{C} \phi 6, \mathrm{~d},{ }^{3} J_{\mathrm{CF}}=8.5\right), 115.46$ 
$\left(\mathrm{C} \phi 3\right.$ and $\left.\mathrm{C} \phi 5, \mathrm{~d},{ }^{2} J_{\mathrm{CF}}=21.7\right), 102.74(\mathrm{C} 5), 90.66\left(\mathrm{C} 1{ }^{\prime}, \mathrm{d},{ }^{6} J_{\mathrm{CF}}=1.4\right), 54.38\left(\mathrm{C} 2-\mathrm{OCH}_{3}\right), 54.08(\mathrm{C} 4-$ $\left.\mathrm{O}^{-} \mathrm{H}_{3}\right), 8.98\left(\mathrm{C}^{-}-\underline{\mathrm{CH}}_{3}\right)$.

4K: ${ }^{13} \mathrm{C}-\mathrm{NMR}$ (DMSO- $\left.d_{6}\right) \delta: 194.57\left(\mathrm{C} 2\right.$ '), $169.09(\mathrm{C} 4), 165.11\left(\mathrm{C} \phi 4, \mathrm{~d},{ }^{1} J_{\mathrm{CF}}=251.6\right), 163.19(\mathrm{C} 6)$, $162.14(\mathrm{C} 2), 133.12\left(\mathrm{C} \phi 1, \mathrm{~d},{ }^{4} J_{\mathrm{CF}}=3.3\right), 131.39\left(\mathrm{C} \phi 2\right.$ and $\left.\mathrm{C} \phi 6, \mathrm{~d},{ }^{3} J_{\mathrm{CF}}=9.6\right), 115.73(\mathrm{C} \phi 3$ and $\mathrm{C} \phi 5, \mathrm{~d}$, $\left.{ }^{2} J_{\mathrm{CF}}=22.0\right), 109.08(\mathrm{C} 5), 54.01\left(\mathrm{C} 2-\underline{\mathrm{CCH}}_{3}\right), 53.95\left(\mathrm{C} 4-\mathrm{O} \underline{C H}_{3}\right), 45.00\left(\mathrm{C} 1{ }^{\prime}\right), 9.75\left(\mathrm{C} 5-\underline{C H}_{3}\right) ; \mathrm{MS} \mathrm{m} / z$ $291(\mathrm{MH})^{+}$; Anal. calcd. for $\mathrm{C}_{15} \mathrm{H}_{15} \mathrm{FN}_{2} \mathrm{O}_{3}: \mathrm{C}, 62.06 ; \mathrm{H}, 5.21 ; \mathrm{N}, 9.65$. Found: C, 61.94; H, 5.22; N, 9.69 .

6-[2-(2'-Fluorobenzyl)-2-hydroxypropyl]pyrimidin-2,4-dione (6)

A mixture of compound $5(0.08 \mathrm{~g}, 0.27 \mathrm{mmol})$, chlorotrimethylsilane $(0.12 \mathrm{~mL}, 0.95 \mathrm{mmol})$ and $\mathrm{NaI}(0.14 \mathrm{~g}, 0.95 \mathrm{mmol})$ in anhydrous acetonitrile $(6 \mathrm{~mL})$ was stirred at room temperature for $18 \mathrm{~h}$ and then at $60{ }^{\circ} \mathrm{C}$ for $3 \mathrm{~h}$ under argon atmosphere. The solvent was evaporated under reduced pressure, and the residue was chromatographed using dichloromethane-methanol $=25: 1$ as eluent to give 6 . Yield $=50 \mathrm{mg}(66.4 \%) ; \mathrm{mp}=157-159{ }^{\circ} \mathrm{C} .{ }^{13} \mathrm{C}-\mathrm{NMR}\left(\mathrm{DMSO}-d_{6}\right) \delta: 163.97(\mathrm{C} 4), 160.91\left(\mathrm{C} \phi 2, \mathrm{~d},{ }^{1} J_{\mathrm{CF}}\right.$ $=243.4), 152.95(\mathrm{C} 6), 151.32(\mathrm{C} 2), 133.38\left(\mathrm{C} \phi 6, \mathrm{~d},{ }^{3} J_{\mathrm{CF}}=5.0\right), 128.32\left(\mathrm{C} \phi 4, \mathrm{~d},{ }^{3} J_{\mathrm{CF}}=8.2\right), 124.25$ $\left(\mathrm{C} \phi 1, \mathrm{~d},{ }^{2} J_{\mathrm{CF}}=15.9\right), 123.78\left(\mathrm{C} \phi 5, \mathrm{~d},{ }^{4} J_{\mathrm{CF}}=3.3\right), 114.88\left(\mathrm{C} \phi 3, \mathrm{~d},{ }^{2} J_{\mathrm{CF}}=23.1\right), 100.81(\mathrm{C} 5), 71.52(\mathrm{C} 2$ ', $\left.\mathrm{d},{ }^{4} J_{\mathrm{CF}}=1.1\right), 43.66\left(\mathrm{C} 1^{\prime}, \mathrm{d},{ }^{5} J_{\mathrm{CF}}=0.6\right), 40.86\left(\mathrm{C} 3{ }^{\prime}, \mathrm{d},{ }^{3} J_{\mathrm{CF}}=5.5\right), 25.13\left(\mathrm{C}^{\prime}-\underline{C H}_{3}, \mathrm{~d},{ }^{5} J_{\mathrm{CF}}=1.4\right)$; MS $m / z 277$ (M-H); Anal. calcd. for $\mathrm{C}_{14} \mathrm{H}_{15} \mathrm{FN}_{2} \mathrm{O}_{3}$ : C, 60.42; H, 5.43; N, 10.07. Found: C, 60.61; H, 5.41; N, 10.11 .

6-[2-(4'-Fluorophenyl)-1-propenyl]-5-methylpyrimidin-2,4-dione (8) and 6-[2-(4'-fluorophenyl)-2hydroxypropyl]-5-methylpyrimidin-2,4-dione (9)

The deprotection of 7 was performed in the same manner as described for $\mathbf{6}$. Reagents used were: compound 7 (0.26 g, $0.84 \mathrm{mmol})$, chlorotrimethylsilane $(0.37 \mathrm{~mL}, 0.84 \mathrm{mmol})$ and $\mathrm{NaI}(0.44 \mathrm{~g}$, $2.94 \mathrm{mmol})$ in anhydrous acetonitrile $(7 \mathrm{~mL})$. After column chromatography using dichloromethanemethanol $=40: 1$ as eluent crystalline compounds 8 and 9 were isolated. 8: Yield $=50 \mathrm{mg}(24.4 \%)$; $\mathrm{mp}=140-142{ }^{\circ} \mathrm{C} ;$ 9: Yield $=60 \mathrm{mg}(27.3 \%) ; \mathrm{mp}=192-194{ }^{\circ} \mathrm{C}$.

8: ${ }^{13} \mathrm{C}-\mathrm{NMR}\left(\mathrm{DMSO}-d_{6}\right) \delta: 164.89(\mathrm{C} 4), 162.14\left(\mathrm{C} \phi 4, \mathrm{~d},{ }^{1} J_{\mathrm{CF}}=245.0\right), 150.79$ (C2), 145.92 (C6), $141.77\left(\mathrm{C} 2{ }^{\prime}\right), 137.08\left(\mathrm{C} \phi 1, \mathrm{~d},{ }^{4} J_{\mathrm{CF}}=3.3\right), 128.09\left(\mathrm{C} \phi 2\right.$ and $\left.\mathrm{C} \phi 6, \mathrm{~d},{ }^{3} J_{\mathrm{CF}}=8.2\right), 118.05\left(\mathrm{C} 11^{\prime}, \mathrm{d}\right.$, $\left.{ }^{6} J_{\mathrm{CF}}=1.1\right), 115.28$ (Cф3 and $\left.\mathrm{C} \phi 5, \mathrm{~d},{ }^{2} J_{\mathrm{CF}}=21.4\right), 105.55(\mathrm{C} 5), 17.79\left(\mathrm{C}^{\prime}-\underline{\mathrm{CH}}_{3}\right), 10.85\left(\mathrm{C} 5-\underline{\mathrm{CH}}_{3}\right) ; \mathrm{MS}$ $m / z 261[\mathrm{MH}]^{+}$; Anal. calcd. for $\mathrm{C}_{14} \mathrm{H}_{13} \mathrm{~F}_{2} \mathrm{~N}_{2} \mathrm{O}_{2}$ : C, 64.61; H, 5.03; N, 10.76. Found: C, 64.48; H, 5.04; $\mathrm{N}, 10.78$.

9: ${ }^{13} \mathrm{C}-\mathrm{NMR}\left(\mathrm{DMSO}-\mathrm{d}_{6}\right) \delta: 165.34(\mathrm{C} 4), 161.42\left(\mathrm{C} \phi 4, \mathrm{~d},{ }^{1} J_{C F}=242.4\right), 150.84(\mathrm{C} 2), 147.54$ (C6), $144.63\left(\mathrm{C} \phi 1, \mathrm{~d},{ }^{4} J_{C F}=2.6\right), 127.42\left(\mathrm{C} \phi 2\right.$ and $\left.\mathrm{C} \phi 6, \mathrm{~d},{ }^{3} J_{C F}=8.0\right), 114.84(\mathrm{C} \phi 3$ and $\mathrm{C} \phi 5, \mathrm{~d}$, $\left.{ }^{2} J_{C F}=21.0\right), 107.22(\mathrm{C} 5), 74.14(\mathrm{C} 2 '), 43.97(\mathrm{C} 1 '), 29.46\left(\mathrm{C}^{\prime}{ }^{\prime}-\underline{C H}_{3}\right), 10.64\left(\mathrm{C}^{\prime}-\underline{C H}_{3}\right) ; \mathrm{MS} m / z 277$ [M-H]; Anal. calcd. for $\mathrm{C}_{14} \mathrm{H}_{15} \mathrm{FN}_{2} \mathrm{O}_{3}$ : C, 60.42; H, 5.43; N, 10.07. Found: C, 60.30; H, 5.45; N, 10.09. 
6-[2-(4'-Fluorophenyl)-2-hydroxypropyl]-5-methylpyrimidin-2,4-dione (9) and 6-[2-(4'-fluorophenyl)1-propenyl]-2,4-dimethoxy-5-methylpyrimidine (10)

Compound 7 (0.16 g, $0.52 \mathrm{mmol})$ was dissolved in acetyl chloride $(7 \mathrm{~mL})$ and the reaction mixture was refluxed for $5 \mathrm{~h}$. Water $(2 \mathrm{~mL})$ was then added and the reaction mixture was stirred overnight at room temperature. The solvent was evaporated at the reduced pressure and the remaining yellow oil was chromatographed using dichloromethane as eluent, which yielded compounds $\mathbf{9}$ and 10. 9: Yield $=60 \mathrm{mg}(44.3 \%) ; 10:$ Yield $=20 \mathrm{mg}(9.8 \%) ; \mathrm{mp}=66-68{ }^{\circ} \mathrm{C}$.

10: ${ }^{13} \mathrm{C}-\mathrm{NMR}\left(\mathrm{DMSO}-d_{6}\right) \delta: 169.52(\mathrm{C} 4), 162.01\left(\mathrm{C} \phi 4, \mathrm{~d},{ }^{1} J_{\mathrm{CF}}=245.0\right), 162.0$ (C6), 162.0 (C2), $143.03\left(\mathrm{C} 2{ }^{\prime}\right), 139.22\left(\mathrm{C} \phi 1, \mathrm{~d},{ }^{4} J_{\mathrm{CF}}=3.0\right), 128.20\left(\mathrm{C} \phi 2\right.$ and $\left.\mathrm{C} \phi 6, \mathrm{~d},{ }^{3} J_{\mathrm{CF}}=8.2\right), 122.11\left(\mathrm{C} 1{ }^{\prime}, \mathrm{d}\right.$, $\left.{ }^{6} J_{\mathrm{CF}}=1.7\right), 115.24\left(\mathrm{C} \phi 3\right.$ and $\left.\mathrm{C} \phi 5, \mathrm{~d},{ }^{2} J_{\mathrm{CF}}=21.4\right), 108.42(\mathrm{C} 5), 54.10\left(\mathrm{C} 2-\mathrm{OCH}_{3}\right), 53.92\left(\mathrm{C} 4-\mathrm{OCH}_{3}\right)$, $17.85\left(\mathrm{C}^{\prime}-\mathrm{CH}_{3}\right), 9.89\left(\mathrm{C} 5-\underline{\mathrm{CH}}_{3}\right)$; MS m/z $289[\mathrm{MH}]^{+}$; Anal. calcd. for $\mathrm{C}_{16} \mathrm{H}_{17} \mathrm{FN}_{2} \mathrm{O}_{2}: \mathrm{C}, 66.65 ; \mathrm{H}, 5.94$; N, 9.72. Found: C, 66.92; H, 5.93; N, 9.74.

6-[2-(4'-Fluorophenyl)-2-hydroxy-1-ethenyl]-2,4-dimethoxy-5-phenylpyrimidine (13)

The synthesis of $\mathbf{1 3}$ was performed in the same manner as described for $\mathbf{4}$. Reagents used were: compound 11 (138 mg, $0.59 \mathrm{mmol})$, LDA (0.58 mL, $2 \mathrm{M}$ in THF/heptane/ethylbenzene) and ethyl 4-fluorobenzoate $(0.09 \mathrm{~mL}, 0.58 \mathrm{mmol})$ in anhydrous THF $(6 \mathrm{~mL})$. After column chromatography using cyclohexane-ethyl acetate $=6: 1$ as eluent compound $\mathbf{1 3}$ was isolated as crude oil. Yield $=44.3$ $\mathrm{mg}(16.6 \%) .{ }^{13} \mathrm{C}-\mathrm{NMR}$ (DMSO- $\left.d_{6}\right) \delta: 167.99(\mathrm{C} 4), 163.55$ (Cф4, d, $\left.{ }^{1} J_{\mathrm{CF}}=233.5\right), 163.03(\mathrm{C} 2$ '), 162.35 (C6), 160.52 (C2), $134.00\left(\mathrm{C} \phi 1, \mathrm{~d},{ }^{4} J_{\mathrm{CF}}=2.7\right), 132.88\left(\mathrm{C} \phi 1^{\prime}\right), 131.08$ (C $\phi 2$ and $\left.\mathrm{C} \phi 6, \mathrm{~d},{ }^{3} J_{\mathrm{CF}}=8.8\right)$, 130.79 (C $\left.2^{\prime}\right), 129.12$ (C $\left.\phi 3^{\prime}\right), 128.00\left(\mathrm{C} \phi 4^{\prime}\right), 127.87$ (C $\phi 3$ and $\left.\mathrm{C} \phi 5, \mathrm{~d},{ }^{2} J_{\mathrm{CF}}=18.3\right), 122.33$ (C1'), 114.08 (C5), $54.79\left(\mathrm{C} 2-\mathrm{OCH}_{3}\right), 54.55\left(\mathrm{C} 4-\mathrm{OCCH}_{3}\right)$; $\mathrm{MS} \mathrm{m} / z 353[\mathrm{MH}]^{+}$; Anal. calcd. for $\mathrm{C}_{20} \mathrm{H}_{17} \mathrm{FN}_{2} \mathrm{O}_{3}$ : C, 68.17; H, 4.86; N, 7.95. Found: C, 68.37; H, 4.84; N, 7.97.

\section{6-[2-(2'-Fluorobenzyl)-2-hydroxypropyl]-2,4-dimethoxy-5-phenylpyrimidine (14)}

According to the procedure described for $\mathbf{4}$, the synthesis of $\mathbf{1 4}$ was performed using compound $\mathbf{1 1}$ (95 mg, $0.41 \mathrm{mmol})$, LDA $(0.40 \mathrm{~mL}, 2 \mathrm{M}$ in THF/heptane/ethylbenzene) and 2-fluorophenylacetone $(0.09 \mathrm{~mL}, 0.41 \mathrm{mmol})$ in anhydrous THF $(6 \mathrm{~mL})$ as reagents. After column chromatography using petroleum ether-ethyl acetate $=6: 1$ as eluent compound 14 was isolated. Yield $=40.3 \mathrm{mg}(25.7 \%)$. ${ }^{13} \mathrm{C}-\mathrm{NMR}$ (DMSO-d $)$ ) $169.19(\mathrm{C} 4), 161.95\left(\mathrm{C} \phi 2, \mathrm{~d},{ }^{1} J_{\mathrm{CF}}=245.7\right), 166.56(\mathrm{C} 6), 163.02(\mathrm{C} 2), 133.91$ $\left(\mathrm{C} \phi 6, \mathrm{~d},{ }^{3} J_{\mathrm{CF}}=4.7\right), 133.54\left(\mathrm{C} \phi 1^{\prime}\right), 131.25\left(\mathrm{C} \phi 2^{\prime}\right), 130.90\left(\mathrm{C} \phi 4, \mathrm{~d},{ }^{3} J_{\mathrm{CF}}=7.2\right), 129.58\left(\mathrm{C} \phi 3^{\prime}\right), 125.16$ $\left(\mathrm{C} \phi 4^{\prime}\right), 116.24\left(\mathrm{C} \phi 1, \mathrm{~d},{ }^{2} J_{\mathrm{CF}}=14.0\right), 123.77\left(\mathrm{C} \phi 5, \mathrm{~d},{ }^{4} J_{\mathrm{CF}}=3.3\right), 115.00\left(\mathrm{C} \phi 3, \mathrm{~d},{ }^{2} J_{\mathrm{CF}}=22.7\right), 116.25$ (C5), $72.91(\mathrm{C} 2 '), 44.28\left(\mathrm{C} 1^{\prime}\right), 54.89\left(\mathrm{C} 2-\mathrm{OCH}_{3}\right), 54.51\left(\mathrm{C} 4-\underline{\mathrm{CCH}}_{3}\right) .40 .85\left(\mathrm{C} 3{ }^{\prime}, \mathrm{d},{ }^{3} J_{\mathrm{CF}}=5.6\right), 27.14$ $\left(\mathrm{C}^{\prime}-\underline{\mathrm{CH}}_{3}\right)$; MS m/z $383[\mathrm{MH}]^{+}$; Anal. calcd. for $\mathrm{C}_{22} \mathrm{H}_{23} \mathrm{FN}_{2} \mathrm{O}_{3}: \mathrm{C}, 69.09 ; \mathrm{H}, 6.06 ; \mathrm{N}, 7.33$. Found: C, 69.29; H, 6.04; N, 7.31.

\section{Antitumor activity assays}

The colon carcinoma (HCT 116 and SW 620), breast carcinoma (MCF-7) and lung carcinoma (H 460) cells were cultured as monolayers and maintained in Dulbecco's modified Eagle's medium 
(DMEM), while MOLT-4 cells (acute lymphoblastic leukemia) were cultured in suspension in RPMI medium, both supplemented with 10\% fetal bovine serum (FBS), $2 \mathrm{mM}$ L-glutamine, $100 \mathrm{U} / \mathrm{mL}$ penicillin and $100 \mu \mathrm{g} / \mathrm{mL}$ streptomycin in a humidified atmosphere with $5 \% \mathrm{CO}_{2}$ at $37{ }^{\circ} \mathrm{C}$.

The growth inhibition activity was assessed as described previously, according to the slightly modified procedure of the National Cancer Institute, Developmental Therapeutics Program [9,10]. Briefly, the cells were inoculated onto standard 96-well microtiter plates on day 0. Test agents were then added in five consecutive 10 -fold dilutions $\left(10^{-8}\right.$ to $\left.10^{-4} \mathrm{~mol} / \mathrm{L}\right)$ and incubated for further 72 hours. Working dilutions were freshly prepared on the day of testing. The solvent (DMSO) was also tested for eventual inhibitory activity by adjusting its concentration to be the same as in working concentrations (maximal concentration of DMSO was $0.25 \%$ ). After 72 hours of incubation, the cell growth rate was evaluated by performing the MTT assay [10] which detects dehydrogenase activity in viable cells. The absorbency (OD, optical density) was measured on a microplate reader at $570 \mathrm{~nm}$.

Each test point was performed in quadruplicate in three individual experiments. The results are expressed as $\mathrm{IC}_{50}$, which is the concentration necessary for $50 \%$ of inhibition. The $\mathrm{IC}_{50}$ values for each compound are calculated from dose-response curves using linear regression analysis by fitting the test concentrations that give PG (percentage of growth) values above and below the reference value (i.e. $50 \%$ ). Each result is a mean value from three separate experiments.

\section{Cell cycle analysis}

$2 \times 10^{5}$ cells were seeded per well in a 6 -well plate. After overnight incubation, tested compounds were added. After desired length of time, the attached cells were trypsinized, combined with floating cells, washed with phosphate buffered saline (PBS) and fixed with $70 \%$ ethanol. Immediately before the analysis, cells were washed with PBS and incubated with $0.1 \mu \mathrm{g} / \mu \mathrm{L}$ RNAse A at $37{ }^{\circ} \mathrm{C}$ for 15 minutes. Subsequently, cells were stained with $50 \mu \mathrm{g} / \mathrm{ml}$ of propidium iodide (PI) and analyzed by Becton Dickinson FACScalibur flow cytometer. For each analysis, 20,000 events were measured. Measurements were performed in duplicate for two independent experiments. The percentage of the cells in each cell cycle phase was based on the obtained DNA histograms and determined using the ModFit $\mathrm{LT}^{\mathrm{TM}}$ software (Varity House). Statistical analysis was performed in Microsoft Excel by using the ANOVA at $\mathrm{p}<0.05$.

\section{Conclusions}

C-6 fluorophenylalkyl (6, 9, 14 and 15), fluoropenylakenyl (4, 8, 10 and 13) and 5-furyl-6-methyl (12) pyrimidine derivatives were synthesized and evaluated for their cytostatic activities. Among all tested compounds, C-5 furyl (12) and phenyl (13 and 15) substituted pyrimidine derivatives showed the most significant cytostatic activities against all tumor cell lines ( $\mathrm{IC}_{50}$ are in low micromolar range). In the series of C-6 fluorophenylalkyl 5-methylpyrimidines, compounds $\mathbf{8}$ and $\mathbf{1 0}$ containing unsaturated side chains showed better inhibitory effects $\left(8: \mathrm{IC}_{50} \approx 69 \mu \mathrm{M}, 10\right.$ : $\left.\mathrm{IC}_{50} \approx 47 \mu \mathrm{M}\right)$ than their saturated pyrimidine derivatives 7 and 9. Furthermore, among C-6 fluorophenylalkyl 5-phenylpyrimidines, compounds 13 and 15 with a $p$-fluorophenyl moiety in the side chain exhibited the most pronounced antiproliferative activity $\left(13: \mathrm{IC}_{50} \approx 2.5 \mu \mathrm{M}, 15: \mathrm{IC}_{50} \approx 1.6 \mu \mathrm{M}\right)$. Besides, 12 and 15 induced strong changes in the cell cycle of tumor cells (accumulation of cells in G1 phase and drastic 
decrease in the number of cells in S phase), which eventually caused death of tumor cells. Thus, these compounds emerged as the most interesting leading compounds that could be used for further structural optimization.

\section{Acknowledgments}

Support for this study was provided by the Ministry of Science of the Republic of Croatia (Projects \#125-0982464-2925 and \# 098-0982464-2514).

\section{References}

1. Böhm, H.J.; Banner, D.; Bendels, S.; Kansy, M.; Kuhn, B.; Müller, K.; Obst-Sander, U.; Stahl, M. Fluorine in medicinal chemistry. ChemBioChem 2004, 5, 637-643.

2. Dolbier, W.R., Jr. Fluorine chemistry at the millennium. J. Fluorine Chem. 2005, 126, 157-163.

3. Isanbor, C.; O'Hagan, D. Fluorine in medicinal chemistry: A review of anti-cancer agents. $J$. Fluor. Chem. 2006, 127, 303-319.

4. Howard, J.A.K.; Hoy, V.J.; O'Hagan, D.; Smith, G.T. How good is fluorine as a hydrogen bond acceptor? Tetrahedron 1996, 52, 12613-12622.

5. Bergstrom, D.E.; Swartling, D.J. Structure, Reactivity, Synthesis and Applications. In FluorineContaining Molecules; Liebman, J.F.; Greenberg, A.; Dolbier, W.R., Jr., Eds.; VCH: New York, NY, USA, 1988; pp. 259-308.

6. Öğretir, C.; Yaman, M. AM1, PM3 and MNDO study of the tautomeric equilibria of 2-, 4- or 5hydroxypyrimidin derivatives and their azo- and thio- analogs. J. Mol. Struct. (Theochem) 1999, 458, 217-226.

7. Williams, M.; Kowaluk, E.A.; Arneric, S.P. Emerging molecular approaches to pain therapy. $J$. Med. Chem. 1999, 42, 1481-1500.

8. Bradshaw, T.K.; Hutchinson, D.N. 5-Substituted pyrimidine nucleosides and nucleotides. Chem. Soc. Rev. 1977, 6, 43-62.

9. Prekupec, S.; Makuc, D.; Plavec, J.; Kraljević, S.; Kralj, M.; Pavelić, K.; Andrei, G.; Snoeck, R.; Balzarini, J.; De Clercq, E.; Raić-Malić, S.; Mintas, M. Antiviral and cytostatic evaluation of the novel 6-acyclic chain substituted thymine derivatives. Antiviral Chem. Chemother. 2005, 16, 327-338.

10. Prekupec, S.; Makuc, D.; Plavec, J.; Šuman, L.; Kralj, M.; Pavelić, K.; Balzarini, J.; De Clercq, E.; Mintas, M.; Raić-Malić, S. Antiviral and cytostatic evaluation of the novel 6-acyclic chain substituted thymine derivatives. J. Med. Chem. 2007, 50, 3037-3045.

11. Shields, A.F.; Lim, K.; Grierson, J.; Link, J.; Krohn, K.A. Utilization of Labeled Thymidine in DNA Synthesis: Studies for PET. J. Nucl. Med. 1990, 31, 337-342.

12. Schlenker, J. Ueber 4.5-Dimethylpyrimidin. Berichte 1901, 34, 2812-2829.

13. Raić-Malić, S.; Johayem, A.; Ametamey, S.; Batinac, S.; De Clercq, E.; Folkers, G.; Scapozza, L. Synthesis, ${ }^{18}$ F-radiolabelling and biological evaluations of C-6 alkylated pyrimidine nucleoside analogues. Nucleos. Nucleot. Nucleic. Acids 2004, 23, 1707-1721. 
14. Middleton, W.J. New fluorinating reagents. Dialkylaminosulfur fluorides. J. Org. Chem. 1975, 40, 574-578.

15. Agrofoglio, L.A.; Gillaizeau, I.; Saito, Y. Palladium-Assisted routes to nucleosides. Chem. Rev. 2003, 103, 1875-1916.

16. Stille, J.K. The Palladium-catalyzed Cross-coupling reactions of organotin reagents with organic electrophiles [New Synthetic Methods (58)]. Angew. Chem. Int. Ed. Engl. 1986, 25, 508-524.

17. Stille, J.K. Palladium catalyzed coupling of organotin reagents with organic electrophiles. Pure Appl. Chem. 1985, 57, 1771-1780.

18. Gazivoda, T.; Krištafor, S.; Cetina, M.; Nag1, A.; Raić-Malić, S. Synthesis and structural studies of C-5 aryl and C-6 alkyl substituted pyrimidine derivatives. Struct. Chem. 2008, 19, 441-449.

Sample Availability: Samples of compounds 1-15 are available from the authors.

(C) 2009 by the authors; licensee Molecular Diversity Preservation International, Basel, Switzerland. This article is an open-access article distributed under the terms and conditions of the Creative Commons Attribution license (http://creativecommons.org/licenses/by/3.0/). 